\title{
高速圧縮および引張を受けるコンクリート の力学的諸性質について
}

（構造物および構造材料の高速度荷重に対する力学的性質の研究 その 2)

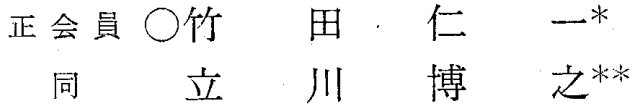

\section{まえがき}

これは筆者等か潐備中の構造物高速度破 壊実験における、鉄筋コンクリート構造基 素実験の一部として行つた、コンクリート 円筒体圧縮わよび引張強さ係数試験の報告 である。昨年予備的な圧縮試験の結果を報 告したが、本武験では常用の配合によるコ ンクリート試験の対象とした。実験装置 は、筆者等が製作した高速度破壤試験機(1)
第 1 表 コンクリートの配合

\begin{tabular}{|c|c|c|c|c|c|c|c|c|c|}
\hline  & 試料番号 & $\begin{array}{l}\text { 水セメ } \\
\text { ント比 }\end{array}$ & $\begin{array}{c}\text { スランプ } \\
(\mathrm{cm})\end{array} \mid$ & $\begin{array}{l}\text { 砂率 } \\
(\%)\end{array}$ & $\begin{array}{l}\text { 有効水量 } \\
\left(\mathrm{kg} / \mathrm{m}^{3}\right)\end{array}$ & $\begin{array}{l}\text { 七メント量 } \\
\left(\mathrm{kg} / \mathrm{m}^{3}\right)\end{array}$ & $\begin{array}{l}\text { 細骨材料 } \\
\left(\mathrm{kg} / \mathrm{m}^{3}\right)\end{array}$ & $\begin{array}{l}\text { 粗骨材量 } \\
\left(\mathrm{kg} / \mathrm{m}^{3}\right)\end{array}$ & $\begin{array}{l}\text { 測定 } \\
\text { 事項 }\end{array}$ \\
\hline 100 & $101 \sim 120$ & 0.40 & 15 & 39.9 & 206 & 515 & 655 & 990 & \multirow{7}{*}{ 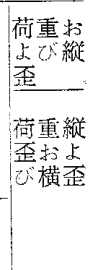 } \\
\hline 200 & $201 \sim 220$ & 0.70 & 15 & 48.1 & 186 & 266 & 917 & 990 & \\
\hline 300 & $301 \sim 320$ & 0.40 & 5 & 45.2 & 173 & 433 & 814 & 990 & \\
\hline 400 & $401 \sim 420$ & 0.70 & 22 & 54.0 & 216 & 309 & 967 & 825 & \\
\hline 500 & $501 \sim 520$ & 0.55 & 15 & 46.3 & 188 & 342 & 851 & 991 & \\
\hline 600 & 620 & 0.55 & 0.5 & 25.0 & 121 & 220 & 530 & 1590 & \\
\hline 700 & $701 \sim 720$ & 0.55 & - & 67.6 & 345 & 627 & 733 & 356 & \\
\hline
\end{tabular}

で計測は抵抗線丕計沉よつた

\section{I 圧 縮試 験}

1.1 計画および、試験体 製作

予備試験においては、水セ メント比、砂率㧍よび有効水 量を少しづつ変えた 3 組のコ ンクリートについて、それら が動的強度におよぼす影響を 調べたが、水セメント比を除 く他の 2 者については、大き な影響は認められなかつた。 そこで、本試験沈いては、 水セメント比の影響を見るこ とを主眼とし、常用配合のコ


ンクリートを実験するため、

1 図コンクリート配合図

JASS 5 鉄筋コンクリート工事標準仕様書 539 表（砂 $5 \mathrm{~mm}$ 以上，砂利 $20 \mathrm{~mm}$ 以下）汃ら 5 種の配合を選定し た。第 1 表抢よび第 1 図にてれを示した。なお、配合が 極端に偏つた場合の影響を調べるため、第 1 表下段の砂 利或は砂が甚しく多い特殊な配合 2 種を加えた。第 1 図 は、配合老 $\mathrm{W} / \mathrm{C}: 1: \mathrm{S} / \mathrm{C}: \mathrm{G} / \mathrm{C}$ (W は有効水量、C, S, G はそれぞれセメント量、細兴材量、粗骨材量。す べて重量とする）と表わし、W/C 在 S/C, G/C 面上の 記数として表わしたものである。1953 年 Watstein が 行つたての種実験 $\left.{ }^{2}\right)(7.5 \mathrm{~cm} \phi \times 15 \mathrm{~cm}$ の試験体によつ た）の配合も記人した。

\footnotetext{
* 防衛大学校土木教室 助教授

** 防衛庁技術研究所第 4 研 研究員
}

使用骨材㹥、多摩川府中附近で採取したもの䒠駼室 内で乾燥篩分け、建築学会標準仕様書に示された粒度䉓 囲のほ添中央の、一定組成になるよう重量で配合した。 試験体は $15 \mathrm{~cm} \phi \times 30 \mathrm{~cm}$ 各シリーズ 20 本を同一バッ 于より製作し、21日間水中養生、以後実験室内江放置 し、試験の 3 日以上前に gage 貼付けた。

gage は $60 \mathrm{~mm}$ 長さのもの在、縦歪、横歪用各 4 枚、 側面中央部対称位置に貼付けた。緹扔よび横歪を測定し たのは、第 1 表に示す No. 300、400，500，600，700 で他は綐昰の計測だけに留めた。

\section{2 実 験}

実験精度を確かめるため、前後 80 本の試験体につい て行つた予備試験の結果は省略する。 
第 2 表 速 度 階

\begin{tabular}{c|c|c|c}
\hline 速度階 & 破壤特間 & 圧縮空気の圧力 & ハルブ開度 \\
\hline I & $1 \sim 2 \mathrm{~ms}$ & $180 \sim 200 \mathrm{~kg} / \mathrm{cm}^{2}$ & $100 \%$ \\
II & $2 \sim 5 \mathrm{~ms}$ & $120 \sim 160$ & $80 \%$ \\
III & $0.01 \sim 0.03 \mathrm{~s}$ & $80 \sim 140$ & バルブ電動 \\
IV & $3 \sim 10 \mathrm{~s}$ & アムスラーの送油ハルブを全開とする \\
$\mathrm{S}$ & $100 \sim 300 \mathrm{~s}$ & 静荷重試験（荷重速度約 $2.5 \mathrm{~kg} / \mathrm{cm}^{2}, \mathrm{sec}$ ) \\
\hline
\end{tabular}

実験は前述したように、筆者等の製作した高速度破壤 陚験機1)を使つて行つた。とれは圧縮空気を動力源とす る油圧試験機で、圧緶空気の圧力とバルブ開度によつて 荷重速度を調節する。計測は荷重、歪共抵抗線歪計に上 り、ブラウン管オッシログラフ又は電磁オッシログラフ に記録した。

荷重速度は第 2 表の 5 段階を目標としたが、速度階I については装置故障のため、計画程速い速度は得られな かつた。計測例および破壊時の状況を写真 $1 、 2$ 亿掍げ た。記録から、荷重速度、変形速度、応力一歪曲線、弾性係
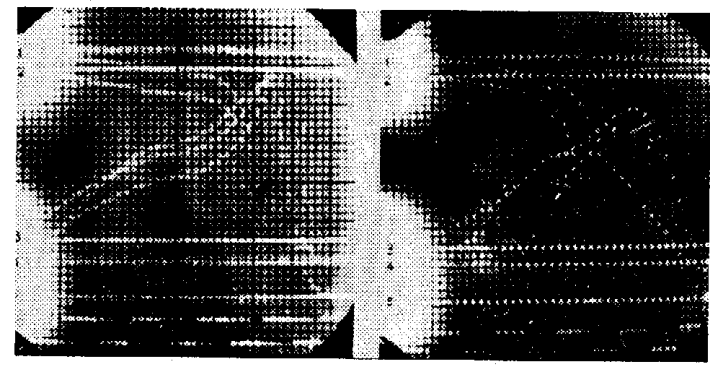

(i) No. 507, 速度階 II $\sigma_{\max }=549 \mathrm{~kg} / \mathrm{cm}^{2}$

(ii) No. 612 速度階 I タイムマーク $500 \mathrm{cps}$ $\sigma_{\max }=383 \mathrm{~kg} / \mathrm{cm}^{2}$ タイムマーク $1000 \mathrm{cps}$ 圧縮試験記録例 1,2 一横歪 3,4 一縰歪 5 一荷重 写真一1

数、吸収エネルギー、 およびポアソン数を求 ๖た。

荷重速度は最大荷重

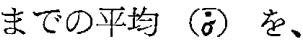
変形速度は同様の平均 （态）および最大荷重の $85 \%$ 己最大荷重間の平 均 $(\bar{\varepsilon} .85)$ を計算し、乙

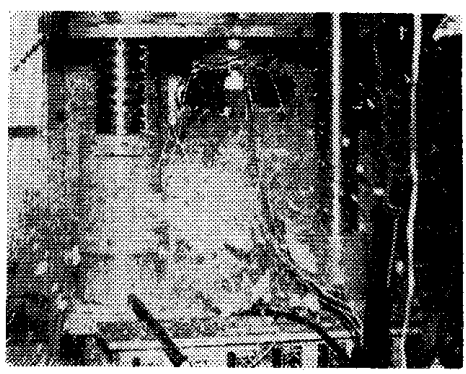

試料番号 . No. 420 速度階 II 写真-2 破壞の状況

れらの何れかによつて結果の諸図表を整理した。試験体 の材令恃平均 90 日である。

\section{1 実験結果}

（1）破壞状洗 試験体が乾燥していたためとも考えら れるが、殆どすべてが最大荷重に達した直後瞬間的に破 壊した。その際荷重が0に戻るまでの時間は 1〜2 millisec. であつた。水セメント比.70 および砂率の低い 600 シリーズの場合にだけ最大荷重点を越して変形の進んだ ものが数例あつた。

（2）圧縮強度 圧縮強度はよく知られているように荷 重速度 (変形速度でも同様である) と共に増大する。乙 れらの関係を第 $2 、 3 、 4$ 図に示した。なお一定歪に対

【記号】 $\oplus \mathrm{NO} .100 \quad \square \mathrm{NO} 0.200 \quad \triangle \mathrm{NO} 0.300 \quad \mathrm{NO} .400$ ONO.500 $\nabla$ NO.600 NO.700

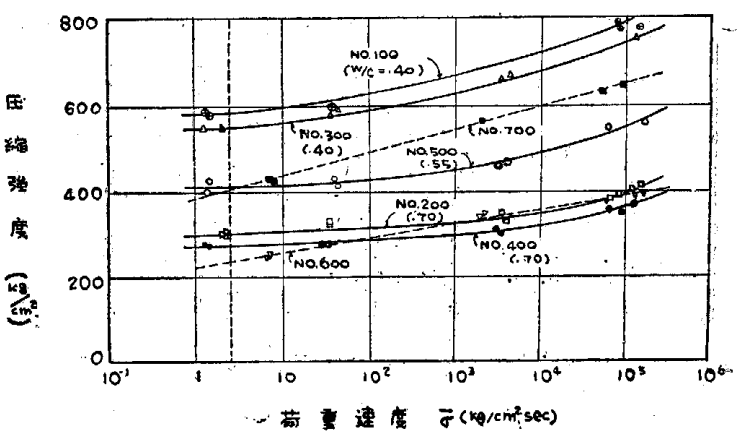

2 図圧縮強度と荷重速度の関係



3 図 荷重速度による压縮強度増加率

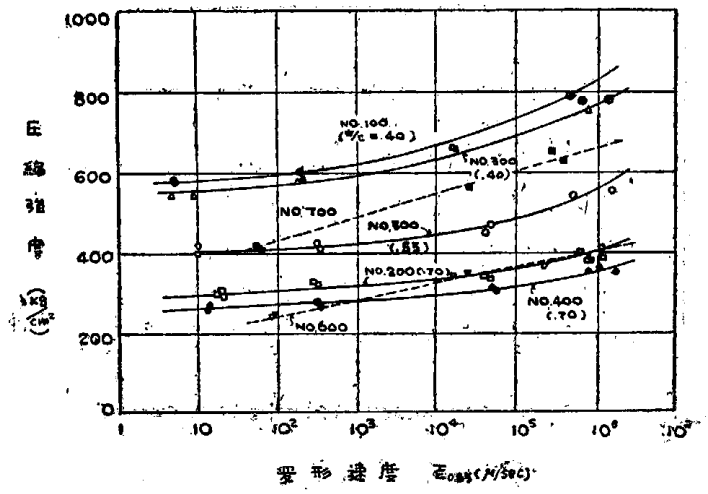

4 図 圧縮強度と変形速度 $\widetilde{\varepsilon}_{0.85}$ との関係



5 図 正 $0.15 \%$ に於ける応力度 $\sigma_{0.15}$ と 平均変形速度 $\bar{\varepsilon}$ との関倸 




6 图応力否曲線例

する応力度も、歪 $0.15 \%$ の場合を例示した第 5 図に見 られるように、上と同様の傾向を持つているが、增加の 模様は異るようである。特殊配合 No. 600,700 はやは り特異な傾向を示すが、一方は豆枚のような、他方はき わのこまかな外観を持つ両者が似た性質を示すのは興味 深い。

第 3 表 共振法による動弾性係数

\begin{tabular}{c|c}
\hline シリーズー & 共振法による動弾性保数 (平均) \\
\hline 100 & $378,000 \mathrm{~kg} / \mathrm{cm}^{2}$ \\
200 & $312,000 "$ \\
300 & $395,000 "$ \\
400 & $396,000 "$ \\
500 & $339,000 "$ \\
600 & $360,000 "$ \\
700 & $302,000 "$ \\
\hline
\end{tabular}

（3）応力一丕曲線 変形速度と共に変る状況は第 6 図 亿見られる。(1)で述べた理由から、最大荷重点までを描 いた。

（4）弾性係数 弾性係数も荷重速度と共に，大さくな る。歪 $0.1 \%$ 抢よび強度の $1 / 2$ 亿打ける Secant modulus $E_{0.1}, E_{1 / 2}$ を第 7,8 図に示した。なお、共振法に上つ て求めた動弾性係数は第 3 表の值である。

(5) 四収エネルギー 四収エネルギーは最大応力点ま

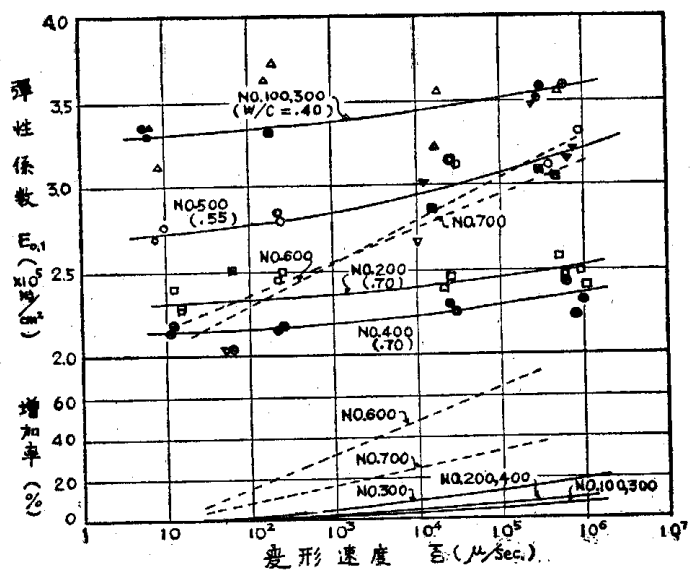

7 図変形速度 $\vec{\varepsilon}$ と弾性係数 $E_{0.1}$ の関倸

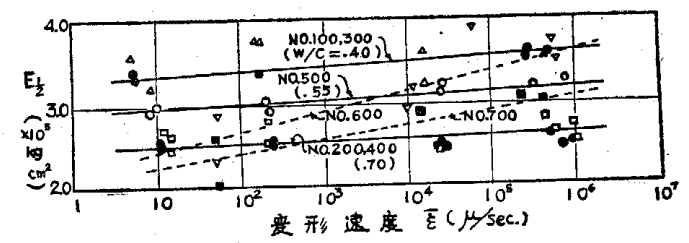

8 图变形速度 $\bar{\varepsilon}$ と弾性係数 $E_{1 / 2}$ の関係



9 図 変形速度 $\bar{\varepsilon}$ と吸収エネルギーの関係

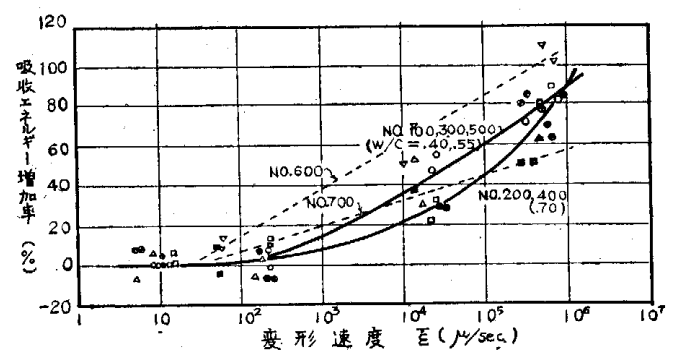

10 図変形速度 $\vec{\varepsilon}$ と吸収エネルギー堌加率の関係


11 図 荷重速度によるポ アソン数 $\mathrm{m}$ の变化 横 軸法応力度 $\sigma$ と強度 $\sigma_{\max }$ の比

で計つたが、第 9、10 図に見られるように、速度と共 に上昇する。乙れは強度が増大すると同時に、最大応力 に対する歪量がわずかに増加するためである。

(6) ポアソン数 第 11 図に、強度に対する応力度の 比を横軸として、ポアソン数の変化を示した。これる荷 
重速度と共に増加する傾向を、見るととが出来る。

\section{II. 引張強さ係数試験}

\section{1 実 験}

試験体は、圧縮陚験に使用した、No. 300，400，600， 700 と同一バッチから採取したもの抒よび、水セメント 比 0.50 、砂率 0.36 の No. 800 である。製作法抢上び 寸法は圧縮武験体と同様であるが、端面の仕上はしてい ない。

ての試験で、試験体を弾性体と考皇れば、端面中央に 水平、垂直に貼つた 2 枚の gage の出力から、理論的に 応力と歪の関係を求めることが出来る。筆者等が行つた ところでは、gage が短いため（長さ $25 \mathrm{~mm} の$ gage を 使つた。）と思われるが、バラッキが多いので、 $60 \mathrm{~mm}$ gage を使つて再試験を行つている。他日に報告した い。ここでは強度についてだけ述べる。

荷重速度は 3 段階とし、圧縮試験の速度階で、I、III Sである。

\section{2 実験結果}

引张咍さ係数も、荷重速度と共偪大し、その割命泆 王縮の場合より大きいようである。乙れらの関係は第12 図に示した。この図で No. 800 が予想される位置から ずれているようであるが、配合が常用のものから大分佰 つているととから洘えると、あり得るととと思われる。 また No. 700 を除くシリーズの增加率曲線は、殆ど重 なるようである。

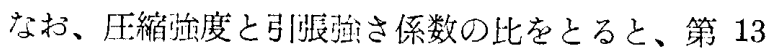
図に見られるとおり、荷重速度に対して、殆ど直線にな るようである。

\section{あとがき}

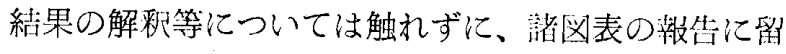
めた。引张強さ係数関する再陚験の結果も含めて別に 厗告したい。俔人的に御指導をいただく勝田博士に心か ら感謝する。
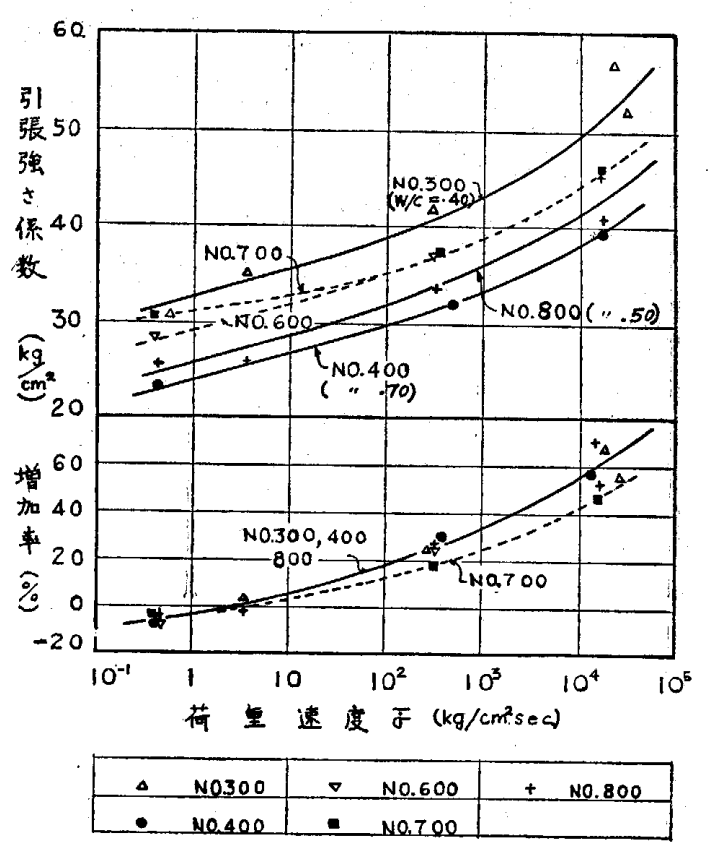

12 図荷重速度と引張強さ係数の関係

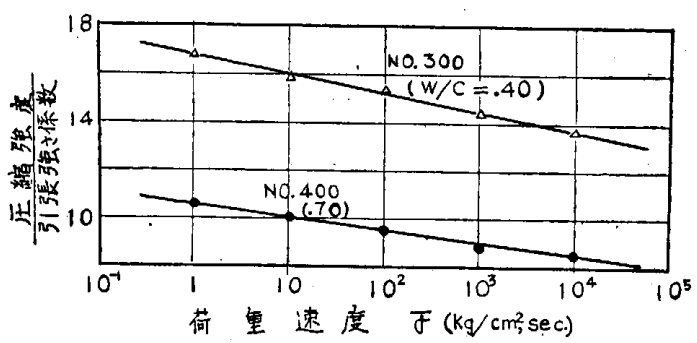

13 図 压維強度と引張強さ係数の比

\section{[参考文献]}

1）竹田仁一・立川博之：高速度荷重試験装置とこれによる コンクリート円筒体压維試験、日本建築学会諭文集第 63 号执よび “A Loading Apparatus for High Speed Testing of Building Materials and Structures.". Proceedings of the Second Japan Congress on Testing Materials, March, 1959.

2) D. Watstein: "Effect of Straining Rate on the Compressive Strength and Elastic Properties of Concrete". Proceedings, Am. Concrete Inst, Vol. 49 (1953) 